
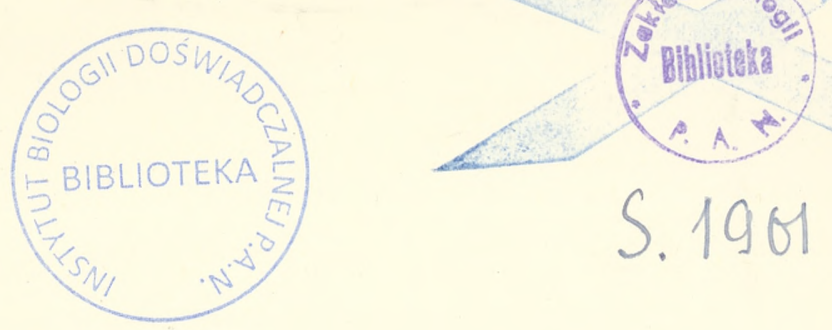

\title{
NOTE ON HESPERIA LUCANUS FABRICIUS (LEPIDOPTERA)
}

\author{
By G. A. Waterhouse, D.Sc., B.E., F.R.E.S.
}

Professor G. D. Hale Carpenter having kindly allowed me to examine Jones' Icones at the Hope Department of Entomology, Oxford University Museum, I am now in a position to show that this name should not be applied to any Australian Lycaenid.

Fabricius (1793, Ent. Syst., 3 (1) : 322, n. 221) described Hesp. lucanus, citing " Jon. fig. pict. 6, tab. 36, fig. 3. Habitat in Indiis Dom. Drury."

Donovan (1800, Ins. India, pl. XLIII, fig. 4) figures the upperside only of this species, cites the reference to Fabricius and quotes the shorter Fabrician description and gives an English translation of it.

An examination of Jones' Icones shows a painting of both the upperside and underside on plate 38 in what is now volume $V$, with the superscription "Fabricis E. S. 221. Lucanus Drury." The underside shows that lucanus is certainly not Australian but very probably a species of LIPTENINAE from Africa. Mr. G. Talbot was with me when this examination was made and agrees with this conclusion.

The Australian species hitherto passing under the Fabrician name lucanus must now be known as Lucia limbaria Swainson (1833, Zool. Illust. (2) 3 : [29], pl. 135). It is curious to note that it was Swainson himself, when describing $L$. limbaria, who suggested that his species might be $H$. lucanus Fab. and so caused the confusion. Butler (1869, Cat. Fabr. Lep. Brit. Mus., : 178) considered $H$. lucanus Fab. to be Australian and referred to a pair obtained in 1846 from Herr J. J. Becker. I have before me what is probably this pair; both bear a disc with 46-46 and the register shows that this collection was purchased from Becker. They are, however, "Thecta" aurifer Blanchard and not $L$. limbaria Swainson, and still less H. lucanus Fabr. Kirby (1871, Syn. Cat. diurn. Lep., : 337) seems to have been the first to place L. limbaria Swainson as a synonym of $H$. lucanus Fabr.

There are still specimens of Paratucia aurifer Blanchard in the British Museum with the specific name lucanus on their labels.

Chrysophanus discifer Herr.-Schaeffer (1869, Stettin. ent. Ztg., 30 : 72, pl. 4, fig. 21) is a synonym.

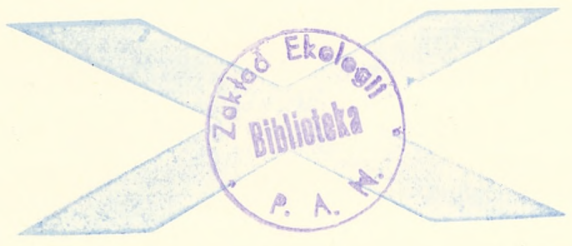

PROC. R. ENT. SOC. LOND. (B) 6. PT. 1. (JAN. 1937.) 
rcin.org.pl 